J. Product. \& Dev., 22(3): 729 - 749 (2017)

\title{
EFFECT OF SILICON, POTASSIUM AND CALCIUM COMPOUNDS ON GROWTH AND INCREASE THE EFFICIENCY OF CITRUS SEEDLINGS TO RESIST CITRUS LEAFMINER (Phyllocnistis citrella).
}

\author{
M.M.S. Abo El-Enien ${ }^{1}$;Aml, B. Abo El-Kassim ${ }^{2}$; A.M. El-Azaze ${ }^{1}$ and \\ F.S. El-Sayed ${ }^{1}$ \\ 1-Citrus Department, Hort. Res. Inst. Agric. Res. Center, Giza, Egypt. \\ 2- Plant Protection Inst. Agric. Res. Center, Giza, Egypt. \\ *Corresponding author: aboeleninmsaad@gmail.com
}

\begin{abstract}
Citrus leafminer is a serious pest of citrus, it cause an economic loses in nurseries and new plantings by decreasing growth rates. Therefore, a greenhouse experiment was carried out during 2014 and 2015 seasons in a private nursery at Kafr El-Sheikh Governorate, Egypt, to study the effect of silicon, potassium and calcium applications on growth and improvement the efficiency of Valencia orange seedlings to resist citrus leafminer. Nine treatments were arranged in randomized complete block design as soil and foliar applications of potassium silicate, silicon oxide, calcium and potassium nitrate beside control.

The highest values of most growth measurements were recorded by potassium nitrate followed by potassium silicate as soil and foliar applications compared with the other treatments. All treatments enhanced leaf $N, P, K$ and Si contents as compared to the control. Citrus leafminer infestation $\%$ and its severity were reduced with potassium silicate treatment which recorded the lowest values. The best anatomical structures of leaves were recorded with potassium silicate treatments compared to the control.

In addition to, the positive effect on increasing the seedlings growth and reducing the percentage of leaves infestation, which help nursery men to get high net income due to sale more seedlings with higher price and preserve environment by reducing amount of insecticide used in controlling citrus leafminer.
\end{abstract}

Key words: Citrus seedlings, silicon, potassium, calcium, growth and leafminer 


\section{INTRODUCTION}

Citrus is a major fruit crop cultivated in Egypt as its acreage, production and exportation potentialities are concerned. It is the largest horticultural industry, during the last few years, and harvested area increased rapidly from year to another, it reached 541723 fed. in 2013 from the total fruit crops area, which estimated to be 1624250 fed. according to Ministry of Agriculture and Land Reclamation (2014). Number of Citrus nurseries also increased to meet the great expected demand as result of replanting tree loss by aging and infected trees by bacterial, virus and viruslike diseases and the expansion to new land. Citrus leaf miner (CLM), Phyllocnistis citrella Stainton is one of the major constraints to citrus production. In addition CLM invasion was recorded in Egypt at the end of 1994, when reported in newly reclaimed areas (Metwally et al., 1998). All citrus cultivars are attacked, small eggs are laid individually on young leaves (Knapp el al., 1995) and then the hatched larvae produce serpentine mines beneath the leaf epidermis, where they feed upon the leaf cells. The damaged areas turns into colortic patch which may become necrotic. The larvae consume about $1-7 \mathrm{~cm}^{2}(40-50 \%)$ of the leaf area, thus adversely affect photosynthesis. The injury is particularly severe in nursery plants and new plantations while the damage is less significant in mature trees (GarciaMarí et al., 2002).

The Economic losses in citrus nursery industry, caused by CLM are owed mainly to decrease number of healthy seedlings and the increase in cost of protecting nurseries (Zhang et al., 1994).Citrus nursery production systems are particularly susceptible to leafminer damage, as seedlings are continuously bearing newly flushes. Many reports, suggest that young trees can be destroyed by leafminer feeding. Nursery men in Florida, considered citrus leafminer as the most important pest, throughout a survey conducted in 1996, (Villanueva-Jiménez and Hoy, 1998).

The citrus leafminer is an invasive herbivorous insect and its feeding causes severe damage to new flush resulting in leaf drop, sunscald, stunting and delay of maturity in young trees. Visual damage from the mining also results in decreased sales of citrus nurseries (Heppner and Fasulo, 2010). Nursery citrus growers in Egypt treat for CLM several times per season primarily with the insecticide. The limitations and high cost of chemical control, in addition to toxicological problems such as insecticide persistence and resistance, justify the adoption of alternative management strategy (Vianna et al., 2009). Bottom-up methods of insect population management focus on modifying the host plant, often by strengthening plant defenses 
through nutrient management. Silicon fertilizer has the potential to be a valuable pest management tool in integrated pest management systems. Soluble silicon $(\mathrm{Si})$ products, such as potassium silicate $\left(\mathrm{K}_{2} \mathrm{SiO}_{3}\right)$, are commercially available as a plant nutritional supplement and can be easily incorporated into irrigation. Application of silicates provides regulation of insect populations by strengthening plant cells and inducing other plant defenses (Epstein, 1999). Silicon (Si) has widely been reported to increase the growth and yield of many crops of agricultural and horticultural importance (Guntzer et al. 2012). There is also an abundance of evidence that $\mathrm{Si}$ induces a variety of plant defenses to both biotic and abiotic stressors (Correa et al., 2005). Calcium and potassium nitrate are easily soluble in water and absorbed by plants. Water soluble calcium or potassium and nitrate combination is its major characteristic. Inherent nitrate content enables many other nutrients as well as calcium to be taken by plants and increases resistance to pests and diseases in addition to improve quality and yielding. Both calcium and potassium are the essential nutrients which are multi - functional in plant physiology and vital for vegetative growth (Marschner, 1995).

Therefore, the main purpose of the paper is to investigate the effect of soil and foliar applications of silicon, potassium and calcium on growth, leaf mineral contents and increase the efficiency of citrus seedlings to resist citrus leafminer under greenhouse.

\section{MATERIALS AND METHODS}

The present study was carried out on Valencia orange (Citrus Sinensis L. Osbeck) seedlings budded on Volkamer lemon rootstock in a private nursery at El-Mofty village, Sidy Salim region, Kafr El-Sheikh Governorate, Egypt, during 2014 and 2015 seasons. To study the effect of soil and foliar applications of potassium silicate $\left(10 \% \mathrm{~K}_{2} \mathrm{O}+25 \% \mathrm{SiO}_{2}\right)$, silicon oxide, potassium nitrate $\left(13.75 \% \mathrm{~N}+44.5 \% \mathrm{~K}_{2} \mathrm{O}\right)$ and calcium nitrate $(15.5 \% \mathrm{~N}+18 \% \mathrm{Ca})$ on growth, leaf mineral content, leaf anatomical structure and percentage of infestation by Phyllocnistis citrella. Homogenous and normally growing seedlings planted in plastic black bags $(17 \times 30 \mathrm{~cm})$ filled with $(25 \%$ peat-moss $+75 \%$ sandy soil $)$ in the greenhouse were carefully selected and were routinely irrigated whenever it is needed. Moreover, NPK (20\% N: $20 \% \mathrm{P}: 20 \% \mathrm{~K})$ solution $\left(1.0 \mathrm{~g} \mathrm{~L}^{-1}\right)$ was added weekly as liquid fertilizer with tap water without any chemical pest control throughout the whole period of study. The scion length of the 
selected seedlings was $5-7 \mathrm{~cm}$ at the beginning of experimental in both seasons ( $2^{\text {th }}$ week of February) and free of leafminer infestation.

Nine treatments were arranged in randomized complete block design with three replicate, ten seedlings per each replicate $(9 \times 3 \times 10)$, thus 270 seedlings were used in the first season, 2014 and the same was done with other seedlings in the second season, 2015.

1. Control (tap water spray).

2. Potassium silicate as soil application.

3. Potassium silicate as foliar application

4. Silicon oxide applied as soil application

5. Silicon oxide as foliar application

6. Calcium nitrate as soil application

7. Calcium nitrate as foliar application

8. Potassium nitrate as soil application

9. Potassium nitrate as foliar application

All soil applications were add at $10 \mathrm{~g} / \mathrm{seedling}$ in the second week of February, while all foliar application at $2 \mathrm{~g} / \mathrm{l}$ in the second week of February and the first week of May and July.

\section{The following data was recorded:}

\section{1- Vegetative growth measurements:}

Plant height $(\mathrm{cm})$ was measured from the soil surface to the top of plant, number of shoots and leaves/ plant, scion length $(\mathrm{cm})$ and diameter $(\mathrm{mm})$, percentage of scion length increment, plant fresh and dry weight and total green color was determined on mature leaves by the SPAD-501 (Minolta Corp, Ramsey, N.J.) according to Marquard and Tiopton (1987).

\section{2- Leaf characteristics:}

Leaf specific weight $\left(\mathrm{mg} / \mathrm{cm}^{2}\right)$ was calculated as stated by Ferre and Forshey (1988),) and hard leaf character in response to investigated treatments were determined during both seasons according to Laz (1999) as well as leaf area $\left(\mathrm{cm}^{2}\right)$ was estimated using formula: Leaf area $=2 / 3 \mathrm{x}$ length $\mathrm{x}$ width as described by Chou (1966).

\section{3- Leaf mineral content:}

Ten healthy and mature leaves (six months age) per each replicate were taken in both seasons. Then, leaves samples were wiped free of dust with a damp cloth, washed with tap water, distilled water and oven dried at $70^{\circ} \mathrm{C}$ 
till a constant weight. After that, $0.2 \mathrm{~g}$ of each ground sample was digested using the procedure suggested by Jackson (1958).

The digested solution was used for the determination of $\mathrm{N}, \mathrm{P}, \mathrm{K}$ and $\mathrm{Ca}$ nutrients as described by A.O.A.C. (1990) while, leaf silicon content was determined according to Dai et al., (2005).

\section{4- Leaf anatomical structure}

At the end of experimental season (20, November 2015), five fresh leaves per each replicate were collected immediately killed, foxed in FAA solution, dehydrated with normal futile alcohol and paraffin wax $\left(56-58^{\circ} \mathrm{C}\right)$ for infiltration and embedding. Serialtrans v-erase sections were prepared (saffranin and fast-green stain technique were followed, then washed in Canada balsam) then examined microscopically and photographed (Johanson, 1940). The thickness of cuticle, epidermis layers of both upper and lower leaf surfaces, palisade and spongy tissues and area of vascular bundle were measured according to Nassar and El-Sahhar, (1998).

\section{5-Leafminer infestation}

For assessing Phyllocnistis citrella infestation (damage), total number of damaged leaves were counted and divided on total number of leaves of seedling and multiplied by hundred. In this way percent damage was calculated according to Elanchezhyan and Arumugachamy (2015) as follows:

Infested leaves $(\%)=$ damaged leaves/total leaves per seedling x 100 while, Severity of damage $=$ Number of mines/total number of infested leaves.

\section{Economic evaluation}

To throw light on the economic evaluation of silicon, potassium and calcium as soil and foliar application treatments used in this study estimation of production cost materials and other costs (workers and machines), crop value, net income and income over control The estimation of the crop value was done on the basis of the whole sale price during the season as average price of the two seasons.

\section{7- Statistical analysis:}

The design of the experiments was established as complete randomized block design with 3 replicates and analysis of variance was done using new L.S.D at $5 \%$ parameter (Mead et al., 1993). 


\section{RESULTS AND DISCUSSION}

\section{1-Vegetative growth parameters}

Results obtained in Tables (1,2 and 3) revealed that seedlings treated with potassium nitrate as soil and foliar applications increased plant height followed by plants fertilized with potassium silicate as soil or foliar applications compared to control in both seasons. The highest number of shoots per plant were recorded with either soil or foliar applications of potassium silicate, potassium and calcium nitrate treatments without significant differences among them comparing with the lowest number obtained with silicon oxide and control treatments in both seasons. All measurements of scion were increased when seedlings treated with potassium nitrate followed by potassium silicate and calcium nitrate treatment as soil application as compared with control in both seasons (Table 2). The highest plant fresh and dry weight as well as total green color obtained with soil application of potassium silicate, potassium nitrate and calcium nitrate treatments as shown in Table 3.

Table (1). Effect of silicon, potassium and calcium compounds on plant height, number of shoots and leaves/plant of Valencia orange seedlings during 2014 and 2015 seasons.

\begin{tabular}{|l|c|c|c|c|c|c|}
\hline \multirow{2}{*}{\multicolumn{1}{|c|}{ Treatments }} & \multicolumn{2}{c|}{$\begin{array}{c}\text { Plant height } \\
(\mathrm{cm})\end{array}$} & \multicolumn{2}{c|}{$\begin{array}{c}\text { Number of } \\
\text { shoots/plant }\end{array}$} & \multicolumn{2}{c|}{$\begin{array}{c}\text { Number of } \\
\text { leaves/plant }\end{array}$} \\
\cline { 2 - 7 } & 2014 & 2015 & 2014 & 2015 & 2014 & 2015 \\
\hline Control & 67.50 & 68 & 1.63 & 1.77 & 46.33 & 50.33 \\
Potassium silicate (soil) & 82.43 & 79.80 & 3.33 & 3.37 & 50.00 & 55.00 \\
Potassium silicate (foliar) & 79.90 & 80.57 & 3.17 & 3.17 & 45.67 & 45.67 \\
Silicon oxide (soil) & 77.00 & 75.17 & 2.50 & 2.43 & 37.33 & 37.00 \\
Silicon oxide (foliar) & 73.73 & 71.83 & 2.07 & 1.50 & 31.00 & 35.33 \\
Calcium nitrate (soil) & 86.00 & 90.07 & 3.20 & 3.40 & 60.67 & 62.33 \\
Calcium nitrate (foliar) & 81.10 & 80.37 & 2.87 & 3.30 & 53.67 & 53.67 \\
Potassium nitrate (soil) & 95.40 & 94.20 & 3.70 & 3.80 & 70.00 & 68.00 \\
Potassium nitrate (foliar) & 91.70 & 92.10 & 3.81 & 3.50 & 68.00 & 66.33 \\
\hline New L.S.D. at 5\% & $\mathbf{6 . 7 5 1}$ & $\mathbf{4 . 1 0 8}$ & $\mathbf{0 . 9 4 1 7}$ & $\mathbf{0 . 9 5 7 5}$ & $\mathbf{9 . 2 1 4}$ & $\mathbf{1 1 . 9 2}$ \\
\hline
\end{tabular}

These results are in agreement with Kadam et al. (2011) on seedling of Rangpur lime and Khoshbakht et al. (2014) on one-year-old, potted Valencia orange they found that fertilized seedlings with $\mathrm{KNO}_{3}$ significantly increased growth compared with unfertilized one. Improving vegetative growth by potassium nitrate and silicate may be due to the role of potassium in ionic balance is reflected in nitrate metabolism (Jeschke and Wolf, 1985). 
Table (2) Effect of silicon, potassium and calcium compounds on scion length, diameter and increment \% of scion length of Valencia orange seedlings during 2014 and 2015 seasons.

\begin{tabular}{|l|c|c|c|c|c|c|}
\hline \multirow{2}{*}{\multicolumn{1}{|c|}{ Treatments }} & \multicolumn{2}{c|}{$\begin{array}{c}\text { Scion length } \\
\text { (cm) }\end{array}$} & \multicolumn{2}{c|}{$\begin{array}{c}\text { Scion diameter } \\
(\mathbf{m m})\end{array}$} & \multicolumn{2}{c|}{$\begin{array}{c}\text { Increment in scion } \\
\text { length (\%) }\end{array}$} \\
\cline { 2 - 7 } & $\mathbf{2 0 1 4}$ & $\mathbf{2 0 1 5}$ & $\mathbf{2 0 1 4}$ & $\mathbf{2 0 1 5}$ & $\mathbf{2 0 1 4}$ & $\mathbf{2 0 1 5}$ \\
\hline Control & 35.00 & 35.50 & 7.03 & 6.00 & 125.8 & 126.1 \\
Potassium silicate (soil) & 49.93 & 47.30 & 8.00 & 8.00 & 230.6 & 201.2 \\
Potassium silicate (foliar) & 47.40 & 48.07 & 7.06 & 6.57 & 206.5 & 206.1 \\
Silicon oxide (soil) & 44.50 & 42.67 & 6.66 & 6.36 & 187.1 & 171.6 \\
Silicon oxide (foliar) & 41.23 & 39.33 & 6.30 & 5.80 & 166.0 & 150.5 \\
Calcium nitrate (soil) & 53.50 & 57.57 & 8.66 & 8.26 & 245.1 & 266.6 \\
Calcium nitrate (foliar) & 48.60 & 47.87 & 8.20 & 7.96 & 213.5 & 204.9 \\
Potassium nitrate (soil) & 67.00 & 65.27 & 9.06 & 9.16 & 400.4 & 380.2 \\
Potassium nitrate (foliar) & 63.00 & 62.10 & 8.46 & 8.26 & 326.7 & 314.6 \\
\hline New L.S.D. at 5\% & $\mathbf{6 . 8 2 0}$ & $\mathbf{4 . 0 6 7}$ & $\mathbf{1 . 0 7 7}$ & $\mathbf{0 . 6 2 1 7}$ & $\mathbf{4 4 . 6 7}$ & $\mathbf{5 0 . 1 3}$ \\
\hline
\end{tabular}

Table (3) Effect of silicon, potassium and calcium compounds on plant fresh and dry weight and total green color (SPAD) of Valencia orange seedlings during 2014 and 2015 seasons.

\begin{tabular}{|l|c|c|c|c|c|c|}
\hline \multirow{2}{*}{ Treatments } & \multicolumn{2}{|c|}{$\begin{array}{c}\text { Plant fresh weight } \\
\text { (g) }\end{array}$} & \multicolumn{2}{c|}{$\begin{array}{c}\text { Plant dry weight } \\
\text { (g) }\end{array}$} & \multicolumn{2}{c|}{$\begin{array}{c}\text { Total green color } \\
\text { (SPAD) }\end{array}$} \\
\cline { 2 - 7 } & $\mathbf{2 0 1 4}$ & $\mathbf{2 0 1 5}$ & $\mathbf{2 0 1 4}$ & $\mathbf{2 0 1 5}$ & $\mathbf{2 0 1 4}$ & $\mathbf{2 0 1 5}$ \\
\hline Control & 75.77 & 76.33 & 33.43 & 38.43 & 47.30 & 49.57 \\
Potassium silicate (soil) & 85.97 & 85.67 & 38.97 & 42.93 & 61.77 & 62.10 \\
Potassium silicate (foliar) & 76.07 & 74.43 & 36.97 & 35.90 & 59.40 & 60.73 \\
Silicon oxide (soil) & 73.33 & 74.63 & 30.80 & 36.83 & 49.70 & 48.20 \\
Silicon oxide (foliar) & 65.73 & 67.90 & 35.67 & 32.63 & 48.07 & 43.90 \\
Calcium nitrate (soil) & 93.70 & 95.40 & 42.20 & 44.83 & 69.20 & 64.67 \\
Calcium nitrate (foliar) & 91.97 & 89.70 & 40.73 & 41.10 & 70.67 & 65.90 \\
Potassium nitrate (soil) & 98.10 & 96.00 & 46.30 & 47.20 & 70.17 & 67.77 \\
Potassium nitrate (foliar) & 95.70 & 93.80 & 42.00 & 41.50 & 72.63 & 70.80 \\
\hline New L.S.D. at 5\% & $\mathbf{1 6 . 1 5}$ & $\mathbf{9 . 0 9 4}$ & $\mathbf{8 . 8 8 0}$ & $\mathbf{4 . 7 2 7}$ & $\mathbf{7 . 0 8 9}$ & $\mathbf{6 . 3 2 2}$ \\
\hline
\end{tabular}

Also, it may be attributed to the role of silicon in improving water use efficiency by reducing leaf transpiration rate through influencing stomatal movement, and reducing water flow rate in xylem vessels, Xiaopeng et al., (2005). Moreover has been documented that, Si application improve Photosynthetic rate and enhance photochemical efficiency $t$ under salt stress that, may be due to increase in grana number and the enlarge size 
of chloroplasts in leaves or that silicon deposition in the cell wall, gives resistance and hardness, Epstein (1999), resulting in opening angle of leaves and more erect leaves, favoring photosynthesis by improving light interception Zhiming et al., (2015). Same results obtained by Zanetti et al., (2016), as for young cacao plants under water deficit silicon treatment increase photosynthetic rate, and water use efficiency, besides carboxylation efficiency, and also cause stability of cell membranes.

\section{2- Leaf characteristics}

Applying potassium silicate or nitrate and calcium nitrate as soil application were the most effective on leaf area and leaf specific weight (Figures 1and 2). However, the highest values of hard leaf character recorded with potassium silicate treatment followed by potassium nitrate as soil application compared to the control which recorded the lowest values (Figure 3 ). The present results regarding the response of three leaf characteristics supported by the early findings of several investigators. Ibrahim and Al-Wasfy (2014) indicated that using silicon along with potassium effectively raised the leaf area of Valencia orange trees, meanwhile, Abd El-Rahman (2016) on grapevine and EL-Tarawy (2017) on olive transplants found that applying potassium silicate increased leaf physiological characteristics (leaf area, leaf specific weight and hard leaf character) compared with untreated plants.

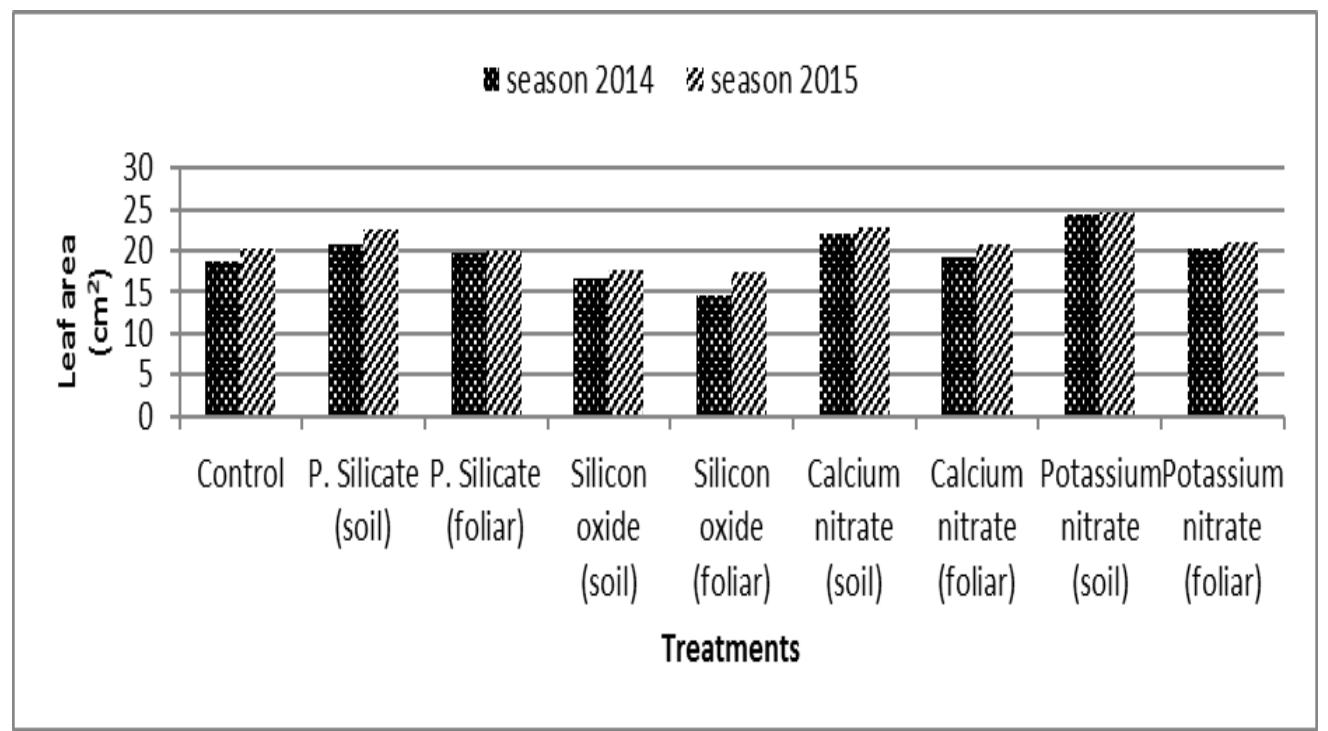

Fig (1): Effect of silicon, potassium and calcium compounds on leaf area of Valencia orange seedlings during 2014 and 2015 seasons. 


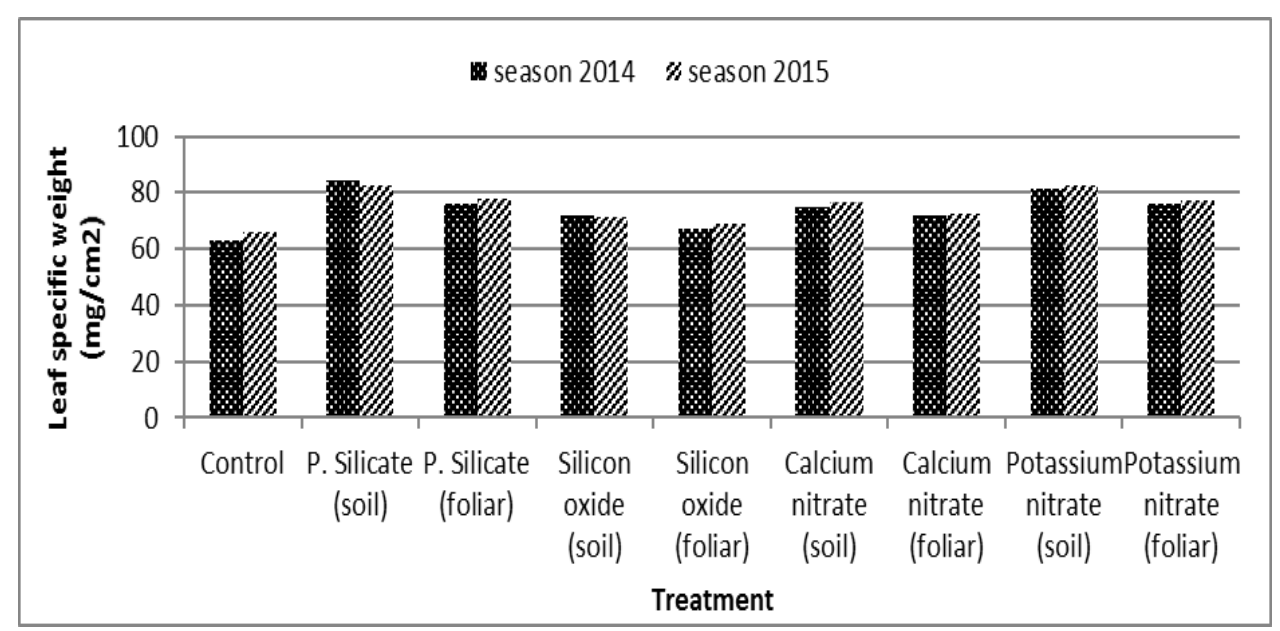

Fig (2): Effect of silicon, potassium and calcium compounds on leaf specific weight of Valencia orange seedlings during 2014 and 2015 seasons.

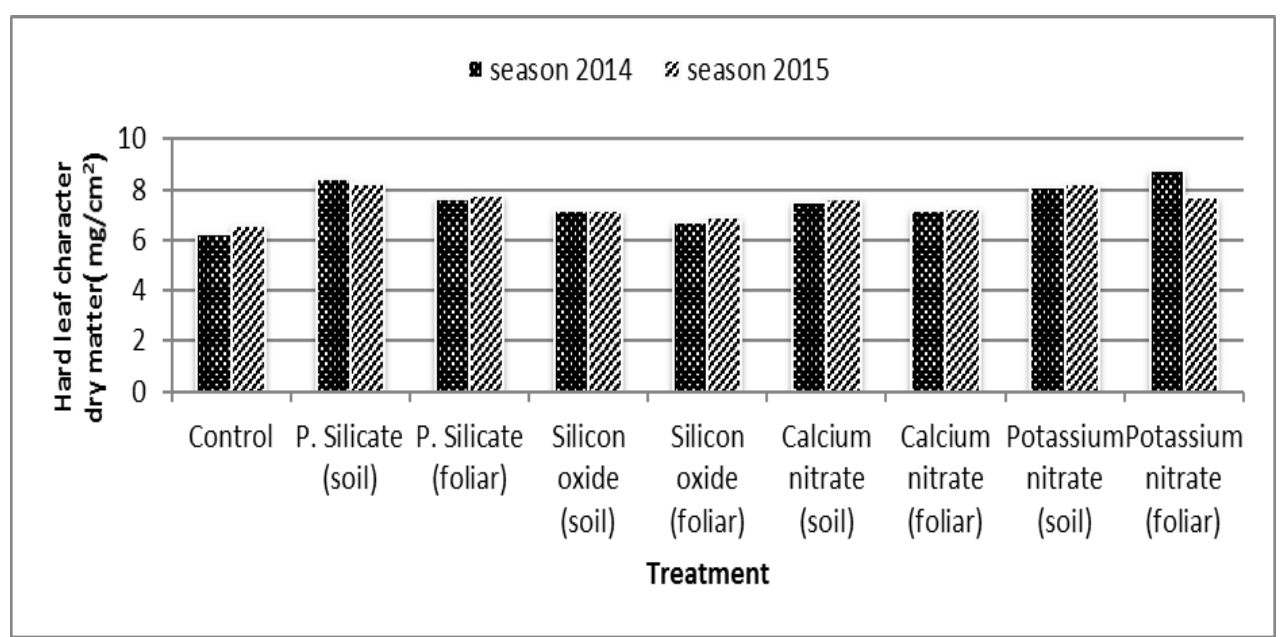

Fig (3): Effect of silicon, potassium and calcium compounds on hard leaf character of Valencia orange seedlings during 2014 and 2015 seasons.

\section{3-Leaf mineral contents}

Results in Table (4) showed that treated seedlings with potassium nitrate as soil or foliar application and calcium nitrate as soil application significantly increased leaf $\mathrm{N}$ and $\mathrm{p}$ contents compared to the other treatments. 
Table (4). Effect of silicon, potassium and calcium compounds on leaf mineral contents of Valencia orange seedlings during 2014 and 2015 seasons.

\begin{tabular}{|c|c|c|c|c|c|c|c|c|c|c|}
\hline \multirow{2}{*}{ Treatments } & \multicolumn{2}{|c|}{$\mathbf{N}(\%)$} & \multicolumn{2}{|c|}{$\mathbf{P}(\%)$} & \multicolumn{2}{|c|}{$\mathbf{K}(\%)$} & \multicolumn{2}{|c|}{ Ca (\%) } & \multicolumn{2}{|c|}{ Si (ppm) } \\
\hline & 2014 & 2015 & 2014 & 2015 & 2014 & 2015 & 2014 & 2015 & 2014 & 2015 \\
\hline Control & 2.35 & 2.39 & 0.123 & 0.124 & \begin{tabular}{|l|l|}
0.697 \\
\end{tabular} & 0.690 & 2.00 & 1.95 & 0.074 & 0.073 \\
\hline P. Silicate (soil) & 2.40 & 2.42 & 0.123 & 0.124 & 0.883 & 0.893 & 2.03 & 2.12 & 0.117 & 0.115 \\
\hline P. Silicate (foliar) & 2.40 & 2.40 & 0.122 & 0.122 & 0.810 & 0.797 & 2.12 & 2.07 & 0.993 & 0.104 \\
\hline Silicon oxide (soil) & 2.31 & 2.35 & 0.122 & 0.123 & 0.747 & 0.698 & 2.03 & 2.07 & 0.095 & 0.093 \\
\hline $\begin{array}{l}\text { Silicon oxide } \\
\text { (foliar) }\end{array}$ & 2.26 & 2.29 & 0.120 & 0.121 & 0.721 & 0.638 & 1.99 & 1.97 & 0.090 & 0.091 \\
\hline $\begin{array}{l}\text { Calcium nitrate } \\
\text { (soil) }\end{array}$ & 2.54 & 2.56 & 0.127 & 0.123 & 0.655 & 0.687 & 2.19 & 3.36 & 0.077 & 0.071 \\
\hline $\begin{array}{l}\text { Calcium nitrate } \\
\text { (foliar) }\end{array}$ & 2.48 & 2.50 & 0.123 & 0.124 & 0.570 & 0.600 & 2.60 & 3.03 & 0.069 & 0.071 \\
\hline $\begin{array}{l}\text { Potassium nitrate } \\
\text { (soil) }\end{array}$ & 2.55 & 2.59 & 0.129 & 0.123 & 0.887 & 0.900 & 2.21 & 2.07 & 0.091 & 0.093 \\
\hline $\begin{array}{l}\text { Potassium nitrate } \\
\text { (foliar) }\end{array}$ & 2.50 & 2.53 & 0.128 & 0.123 & 0.786 & 0.776 & 1.95 & 1.99 & 0.075 & 0.077 \\
\hline New L.S.D. at 5\% & 0.110 & 0.026 & 0.0029 & $\overline{0.0173}$ & 0.0774 & 0.0387 & 1.108 & 0.793 & 0 & 0.0032 \\
\hline
\end{tabular}

The present results are in harmony with the earlier findings of Ebrahim et al., (1993) found that, spraying $\mathrm{KNO}_{3}$ at 0.5 or $1 \%$ increased leaf $\mathrm{K}$ and $\mathrm{N}$ contents of "Balady" mandarin trees. The highest $\mathrm{k}$ content in leaves recorded with potassium silicate treatments as foliar and soil application followed by potassium nitrate treatments comparing with control. In this line, Ibrahim and Al-Wasfy (2014) indicated that using silicon along with potassium effectively raised the level of leaf $\mathrm{K}$ content of Valencia orange trees. As for, leaf Ca content, data showed that soil and foliar application of calcium nitrate gave the highest values in this respect Abd El-Aziz and Ahmed (1995). They found that, spraying "Balady" mandarin trees with $1 \% \mathrm{Ca}\left(\mathrm{NO}_{3}\right)_{2}$ twice $\left(4^{\text {th }}\right.$ week of February and at full bloom) resulted in the most pronounced effect on the leaf content of $\mathrm{N}$, and Ca. Also, El-Tanany et al., (2011) indicated that spraying Washington Navel orange trees with potassium and calcium once, twice or thrice with two concentrations increased leaf $\mathrm{K}$ and $\mathrm{Ca}$ contents. Meanwhile, the highest leaf content of silicon obtained with soil and foliar application of potassium silicate compared with the other treatments in both seasons. These results are in accordance with those obtained by Matichenkov et al., (2001) on grapefruit trees cv. Marsh, and Bekker et al., (2007) on Avocado 
trees. They stated that silicon application resulted in higher $\mathrm{Si}, \mathrm{K}$, concentrations in leaves as compared to untreated plants.

\section{4- Leaf anatomical structure:}

Results obtained in Table (5) and photo (1) cleared various leaf anatomical features responded considerably to treatments. Such trend was true with all six evaluated leaf structure except with the thickness of palisade tissue, which was the unique constant anatomical trait showed the same value in all tested. The highest thickness of cuticle $(\mu)$, upper epidermis, lower epidermis and spongy tissue and largest vascular bundle $\left(\mu^{2}\right)$ were increased under potassium silicate treatment as soil application followed by potassium silicate as foliar application, potassium or calcium nitrate as soil application compared with leaf anatomical traits of untreated seedlings.

Table (5): Some leaf anatomical traits of Valencia orange seedlings in response to soil and foliar applications of silicon, potassium and calcium in 2014 experimental season.

\begin{tabular}{|l|c|c|c|c|c|c|}
\hline \multicolumn{1}{|c|}{ Treatments } & $\begin{array}{c}\text { Cuticle } \\
\text { thickness } \\
(\boldsymbol{\mu})\end{array}$ & $\begin{array}{c}\text { Upper } \\
\text { epidermis } \\
(\boldsymbol{\mu})\end{array}$ & $\begin{array}{c}\text { Lower } \\
\text { epidermis } \\
(\boldsymbol{\mu})\end{array}$ & $\begin{array}{c}\text { Palisade } \\
\text { tissue } \\
(\boldsymbol{\mu})\end{array}$ & $\begin{array}{c}\text { Spongy } \\
\text { tissue } \\
(\boldsymbol{\mu})\end{array}$ & $\begin{array}{c}\text { Area of } \\
\text { vascular } \\
\text { bundle } \\
\left(\boldsymbol{\mu}^{2}\right)\end{array}$ \\
\hline Control & 0.443 & 1.577 & 0.537 & 3.750 & 12.51 & 225.2 \\
Potassium silicate (soil) & 0.697 & 3.033 & 2.270 & 5.037 & 23.20 & 1409 \\
Potassium silicate(foliar) & 0.503 & 2.747 & 1.693 & 4.750 & 22.52 & 1139 \\
Silicon oxide (soil) & 0.506 & 2.307 & 1.197 & 4.497 & 18.58 & 785.8 \\
Silicon oxide (foliar) & 0.503 & 2.263 & 1.157 & 4.043 & 18.11 & 417.1 \\
Calcium nitrate (soil) & 0.580 & 2.470 & 1.343 & 5.037 & 20.21 & 914.7 \\
Calcium nitrate (foliar) & 0.493 & 2.357 & 1.233 & 4.247 & 17.81 & 810.3 \\
Potassium nitrate (soil) & 0.607 & 2.497 & 1.370 & 3.620 & 21.50 & 1134 \\
Potassium nitrate (foliar) & 0.580 & 2.433 & 1.343 & 5.013 & 20.50 & 904.8 \\
\hline New L.S.D. at 5\% & $\mathbf{0 . 1 2 2 4}$ & $\mathbf{0 . 3 1 9}$ & $\mathbf{0 . 2 3 2}$ & $\mathbf{1 . 6 5 0}$ & $\mathbf{1 . 8 5 8}$ & $\mathbf{5 3 . 4 1}$ \\
\hline
\end{tabular}

These results are in the same line with those obtained by Keeping and Meyer (2003) reported that most of the plant silicon occurs in the epidermis, which might dislodge young borer larvae before they can establish in the stem, also they showed that silicon increase the hardness of plant tissue, which interferes with insect larval boring and feeding activity. 


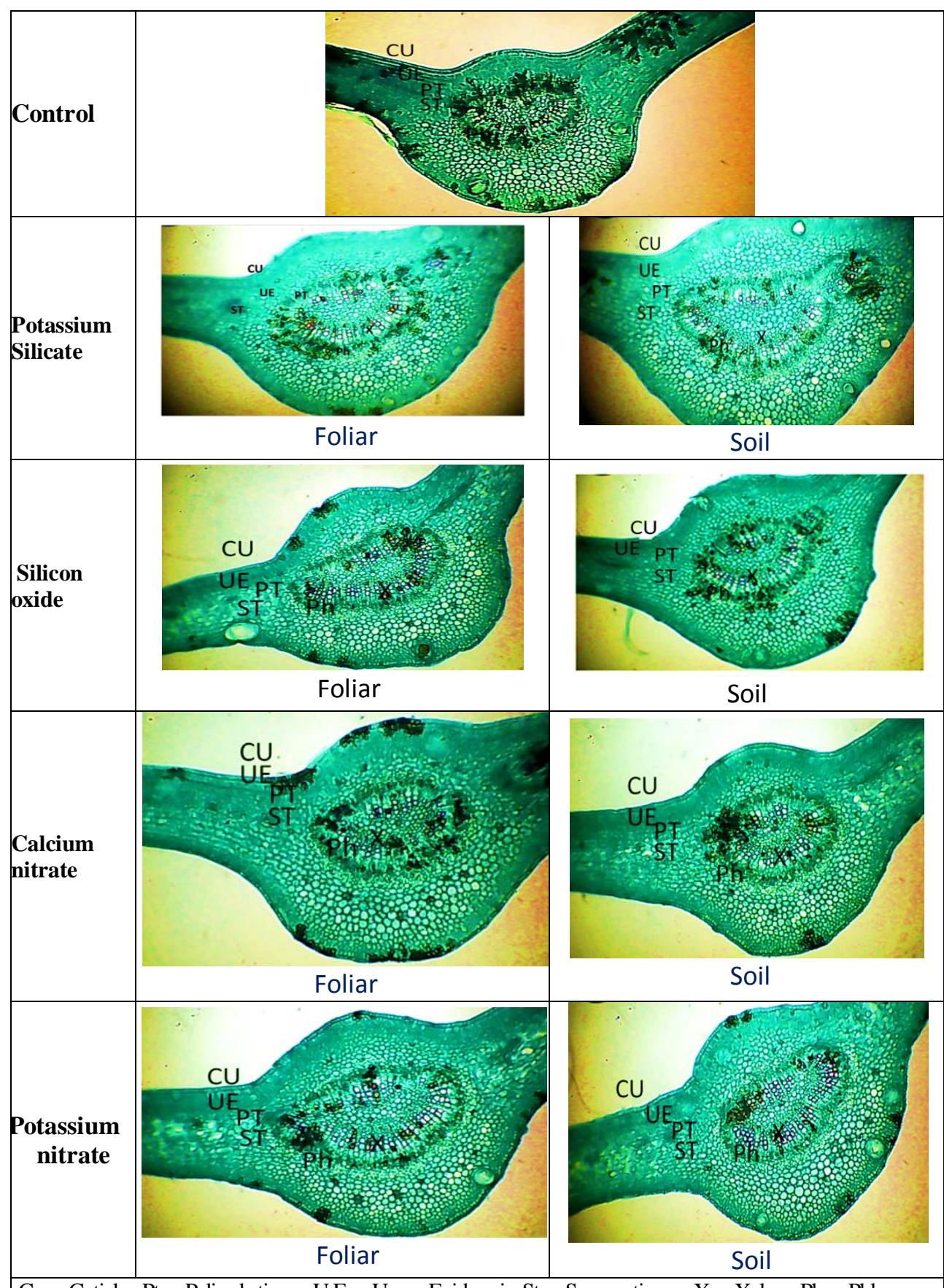

Cu. $=$ Cuticle, Pt. $=$ Palisade tissue, U.E. $=$ Upper Epidermis, St. $=$ Spongy tissue X. $=$ Xylem, Ph. $=$ Phloem.

Photo (1): Effect of soil and foliar applications of silicon, potassium and calcium on leaf anatomical structure of Valencia orange seedlings. 


\section{5- Infestation percentage and severity of citrus leafminer, P. Citrella}

The percentage of infested leaves all over the seasons ranged between 32.11-60.01\% and 19.73- 61.11\% during first and second season, respectively. The highest infestation percentage always was recorded in control plants 60.01 and $61.11 \%$ in the two seasons, respectively. Meanwhile, infestation percentages were reduced in the tested treatments especially potassium silicate as soil application which recorded the lowest percentage (32.11 and 19.73\%) followed by potassium nitrate as soil application (33.69 and 31.53\%) in both seasons, respectively. However, the other treatments gave the intermediate values (Fig 4). Concerning to infestation severity data in Fig (5) illustrated that citrus seedlings treated with potassium silicate as soil application gave the lowest values (1.27 and $1.26 \%)$ compared to control which recorded the highest values (1.57 and $1.99 \%$ ) during 2014 and 2015 seasons, respectively. In general, decreasing infestation percentage and severity damage of CLM may be due to high leaf $\mathrm{Si}$ content and the relation between leaf silicon content and citrus leafminer (CLM) infestation which observed from (Fig. 6) that there are negative correlation between leaf $\mathrm{Si}$ content and infestation percentage of citrus leafminer. The values of correlation coefficient (r) was 0.669 and 0.779 in 2014 and 2015 seasons, respectively (p value at 5\% was 606). These results are in line with those obtained by El-Sayed and Ennab (2008) found that spraying potassium sulphate at $2 \%$ decreased the leafminer infestation on citrus trees, Dito (2016) found that fertilized citrus seedlings with soluble silicon decreased citrus leafminer infection compared with untreated plants. Also, Mustafa et al. (2014) found that there were negative correlation between citrus leafminer infestation and potassium or calcium application. However, Mortezaiefard et al. (2012) indicated that a higher silicon content in the soil reduced the incidence of several crop pests. Moreoever, Chanchal et al. (2016) found that, the most significant effect of silicon on plants, also improving their fitness in adverse environmental conditions and increasing agricultural productivity of plants is the restriction of pest attack and inhibition of diseases. In general, silicon ( $\mathrm{Si}$ ) is involved in plant resistance against insect pest injury through two main defense mechanisms: physical defenses and induced biochemical (chemical) defenses. Si deposited as opaline phytoliths within plants may act as an ant herbivore defenses through increasing hardness and abrasiveness of tissues and wearing of herbivore mouthparts. In order, this would create a feeding deterrent, which may decrease the palatability and digestibility of leaves, thereby potentially impacting on herbivore performance (physical defenses). 
Then again, increasing evidence shows that biochemical changes and induced resistance, because of Si uptake by the plant, are also responsible for the mitigation of insect pest damage. More recently, it has been confirmed that Si plays a positive part in priming plants for a better defense response against pest infestation (Reynolds et al. 2009). The foliar application of silicon-containing compounds in tomato plants was effective against the attack of Tuta. absoluta caterpillars causing detachment of midgut cells from the basal membrane, which may result in digestion difficulties and larval mortality (Santos et al. 2015).

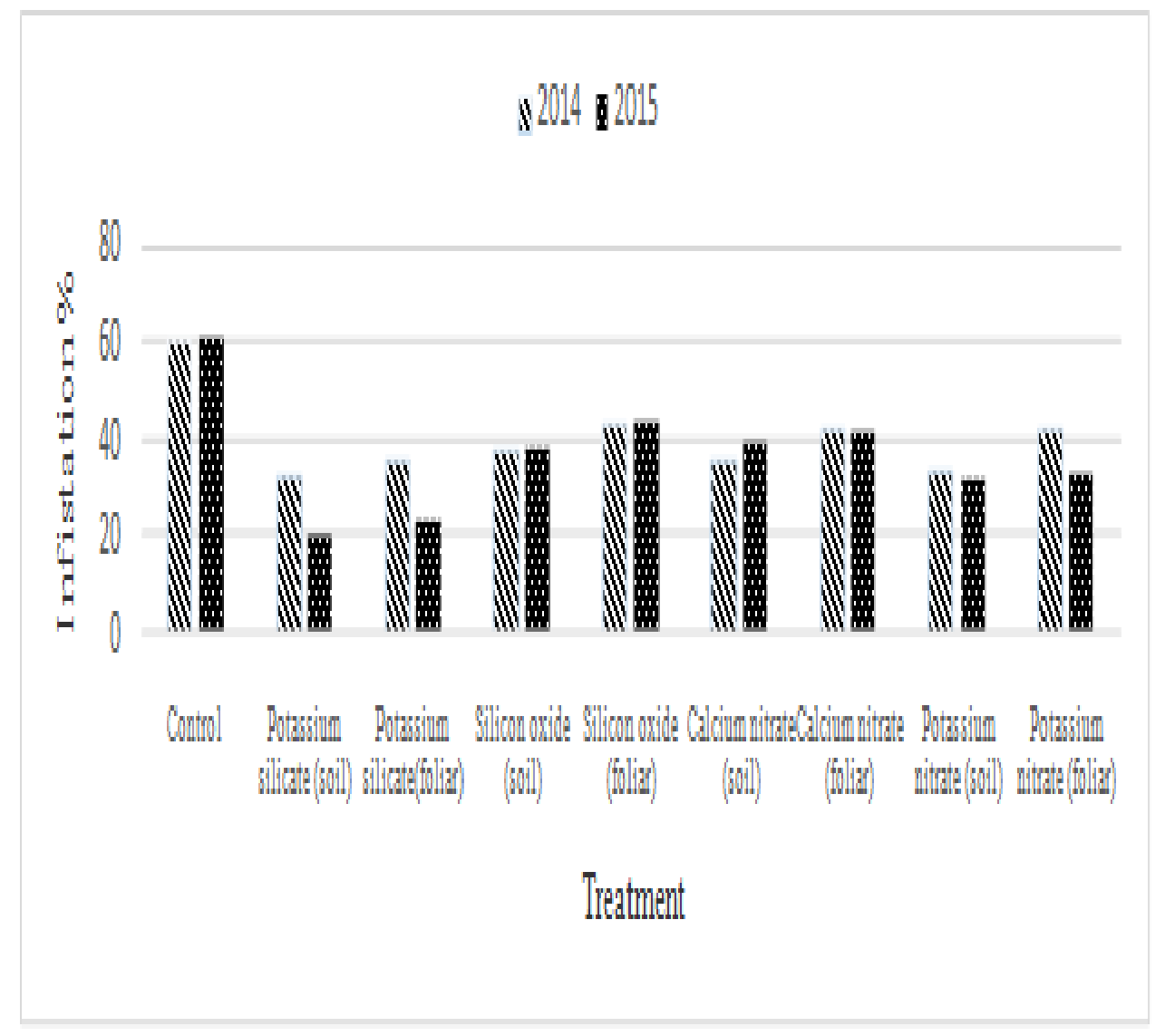

Fig (4): Effect of silicon, potassium and calcium compounds on leafminer infestation percentage of Valencia orange seedlings during 2014 and 2015 seasons. 


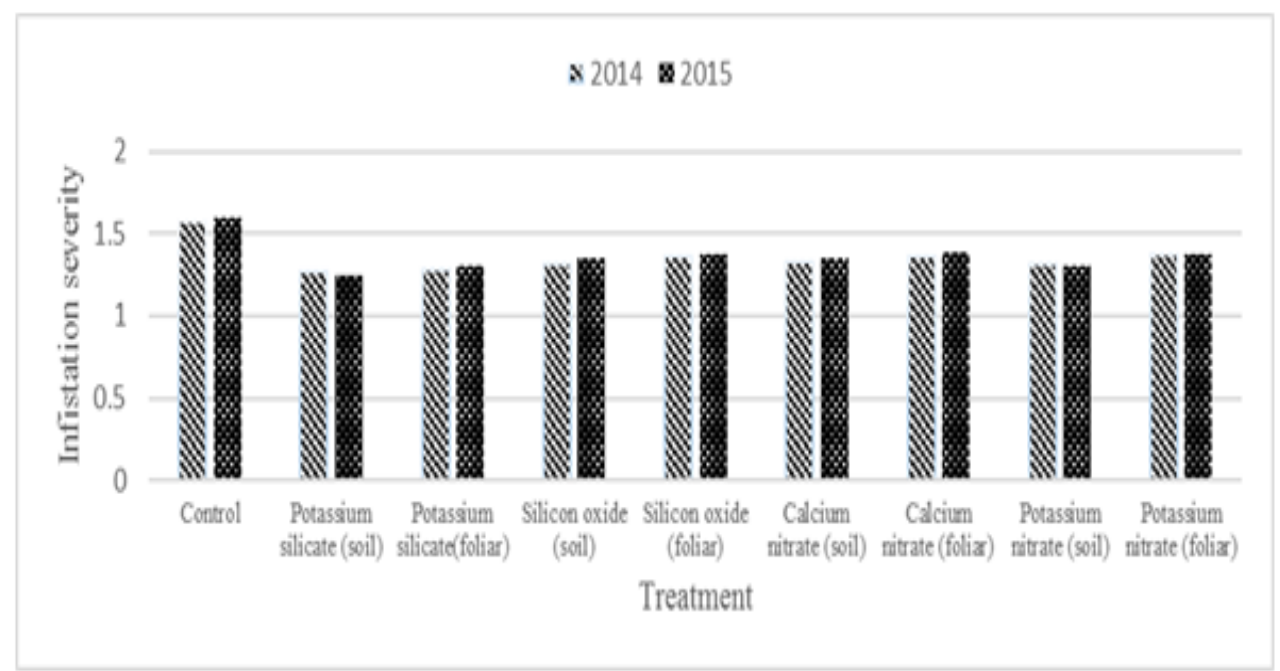

Fig (5): Effect of silicon, potassium and calcium compounds on infestation severity of leafminer on Valencia orange seedlings during 2014 and 2015 season.

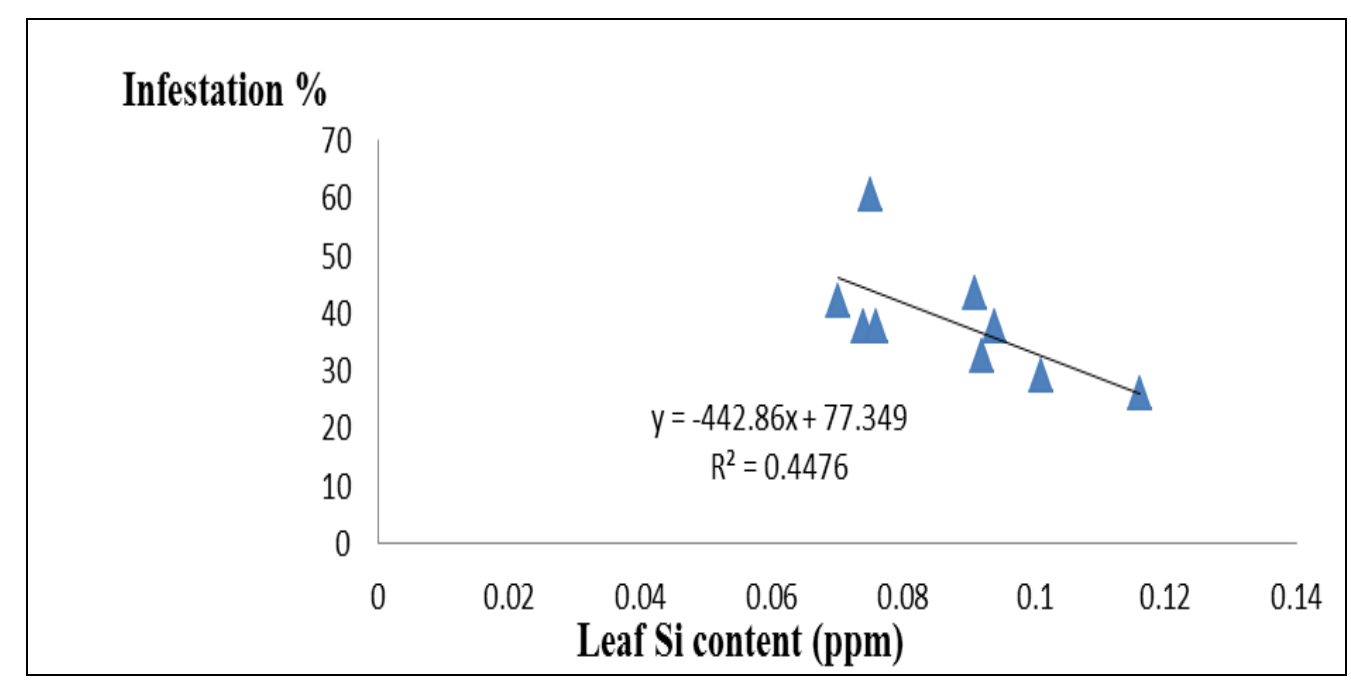

Fig (6). Relation between leaf silicon content and percentage of leafminer infestation on Valencia orange seedlings (as average of 2014 and 2015 seasons. 


\section{6-Economic Evaluation}

The main attention for the farmers to taking a decision regarding the acceptance of new treatments is the economics or net income which will be increase with the new treatment. So, the cost of treatments, crop value and net income were calculated for diverse treatments. In the current experiment, the highest Suitable seedlings with the highest net income was recorded with the treatment of potassium silicate as soil application followed by potassium silicate as foliar application, calcium and potassium nitrate as soil application compared to the lowest values obtained with silicon oxide as soil and foliar application (Table 6).

Table (6). Economic assessment (L.E/100 seedlings) for soil and foliar application treatments of Valencia orange seedlings (as average of 2014 and 2015 seasons).

\begin{tabular}{|c|c|c|c|c|c|c|c|c|c|}
\hline \multirow[b]{2}{*}{ Treatments } & \multirow{2}{*}{$\begin{array}{l}\text { Suitable } \\
\text { seedlings }\end{array}$} & \multirow{2}{*}{$\begin{array}{c}\text { Unsuitable } \\
\text { seedlings }\end{array}$} & \multirow{2}{*}{$\begin{array}{c}\text { Materials } \\
\text { cost } \\
\text { L.E } / 100 \\
\text { seedlings }\end{array}$} & \multirow{2}{*}{$\begin{array}{l}\text { Other } \\
\text { costs }\end{array}$} & \multirow{2}{*}{$\begin{array}{l}\text { Total } \\
\text { costs }\end{array}$} & \multicolumn{2}{|c|}{$\begin{array}{c}\text { Crops value L.E /100 } \\
\text { seedlings }\end{array}$} & \multirow{2}{*}{$\begin{array}{c}\text { Net } \\
\text { income }\end{array}$} & \multirow{2}{*}{$\begin{array}{c}\text { Income } \\
\text { over } \\
\text { control } \\
100 \\
\text { seedling }\end{array}$} \\
\hline & & & & & & $\begin{array}{l}\text { Suitable } \\
\text { seedling }\end{array}$ & $\begin{array}{c}\text { Unsuitable } \\
\text { seedling }\end{array}$ & & \\
\hline Control & 39.37 & 60.93 & 0 & 15 & 15 & 531.50 & 487.44 & 1003.93 & 0 \\
\hline $\begin{array}{l}\text { Potassium } \\
\text { silicate (soil) }\end{array}$ & 74.08 & 25.92 & 50 & 10 & 60 & 1000.08 & 207.36 & 1147.44 & 143.51 \\
\hline $\begin{array}{l}\text { Potassium } \\
\text { silicate } \\
\text { (foliar) }\end{array}$ & 70.87 & 29.13 & 30 & 15 & 45 & 956.75 & 233.04 & 1144.79 & 140.89 \\
\hline $\begin{array}{l}\text { Silicon oxide } \\
\text { (soil) }\end{array}$ & 62.38 & 37.62 & 200 & 10 & 210 & 842.13 & 300.96 & 933.09 & -70.84 \\
\hline $\begin{array}{l}\text { Silicon oxide } \\
\text { (foliar) }\end{array}$ & 56.86 & 43.41 & 120 & 15 & 135 & 763.83 & 347.28 & 976.11 & -27.82 \\
\hline $\begin{array}{l}\text { Calcium } \\
\text { nitrate (soil) }\end{array}$ & 62.39 & 37.61 & 20 & 10 & 30 & 842.27 & 300.88 & 1113.15 & 109.22 \\
\hline $\begin{array}{l}\text { Calcium } \\
\text { nitrate (foliar) }\end{array}$ & 58.02 & 41.98 & 10.5 & 15 & 25.5 & 783.27 & 335.84 & 1093.61 & 89.68 \\
\hline \begin{tabular}{l|} 
Potassium \\
nitrate (soil)
\end{tabular} & 67.39 & 32.61 & 50 & 10 & 60 & 909.77 & 260.88 & 1110.65 & 106.72 \\
\hline $\begin{array}{l}\text { Potassium } \\
\text { nitrate (foliar) }\end{array}$ & 62.20 & 37.80 & 30 & 15 & 45 & 839.70 & 302.4 & 1097.1 & 93.17 \\
\hline
\end{tabular}

*, The average price of suitable seedling (free from CLM) was 13.5 L.E. while unsuitable seedling (unfree from CLM) was 8 L.E in the two seasons according to Ministry of agriculture and Land Reclamation.

Conclusively, it can be concluded that treated citrus seedlings produced under greenhouse with potassium silicate or potassium nitrate as 
soil application at $10 \mathrm{~g} / \mathrm{seedling} /$ or foliar application at $2 \mathrm{~g} / \mathrm{l}$ which had a positive effect on seedlings growth, leaf mineral contents particularly $\mathrm{K}, \mathrm{Ca}$ and $\mathrm{Si}$ and decreased damage of leafminer which can increase sales of citrus nurseries with higher price without risky effects on environment produced by using insecticide.

\section{REFERENCES}

Abd El-Aziz, F.H. and F.F. Ahmed (1995). Effect of number of spray and different concentrations of calcium nitrate fertilizer on Balady mandarin trees. 1. Effect on growth and leaf chemical composition. Minia J. Agric. Res., 8: 82-92.

Abd El-Rahman, A. (2016). Physiological studies on salt tolerance of some grape cultivars rooted cuttings. Ph. D. Thesis. Faculty of Agriculture, Benha Univ., Egypt

A.O.A.C. (1990). Association of Official Agricultural Chemists. Official Methods of Analysis. $15^{\text {th }}$ Ed., Benjamin Franklin Station. Washington, D.C., U.S.A.

Bekker, T. F., N. Labuschagne., T. Aveling and C. Raiiser (2007). Efficacy of water soluble potassium silicate against phytophthora root rot of Avocado under field conditions. South African Avocado Growers Association, Yearbook 30.

Chanchal, M. C.H., R. Kapoor and D. Ganjewala (2016). Alleviation of abiotic and biotic stresses in plants by silicon supplementation. Sci. Agri., 13 (2): 59-73.

Chou, G.J. (1966). A new method of measuring the leaf area of citrus trees. Acta. Hort. Sci., 5: 17-20.

Correa, R.S., J.C. Moraes., A.M. Auad and G.R. Carvalho (2005). Silicon and acibenzolar-Smethyl as resistance inducers in cucumber, against the whitefly Bemisia tabaci (Gennadius) (Hemiptera: Aleyrodidiae) biotype B. Neotropical Entomology, 34(3), 429- 433.

Dai, W.M., K.Q.Zhang., B.W. Duan., C.X.Sun., K. L. Zheng., R. Cai and J.Y. Zhuag (2005). Rapid determination of silicon content in rice. Rice Sci., 12:145-147.

Dito, D. F. (2016). The potential management of citrus leafminer, Phyllocnistis citrella (Stainton) (Lepidoptera: Gracillariidae), by use of soluble silicon fertilizers. Ph.D. Thesis, University of California.USA. 
Ebrahiem, T.A., F.F. Ahmed and K.G. Assy (1993). Behaviour of Balady mandarin trees (Citrus reticulate L.) grown in sandy soil to different forms and concentrations of potassium foliar applications. Assiut $J$. Agric. Sci., 24(3): 215-224.

Elanchezhyan, $\quad K$ and S. Arumugachamy (2015). Evaluation of medium duration rice genotypes against leaffolder, Cnaphalocrocis medinalis Guen. (Pyraustidae: Lepidoptera). International Journal of Fauna and Biological Studies, 2(6):36-37.

El-Sayed, S and H. A. Ennab (2008). Effect of potassium and malathion spraying on citrus leafminer infection in relation to leaf phenols, proline and the used rootstock of Washington Navel and Valencia orange trees. J. Agric. Res. Kafr El-Sheikh Univ., 34(3):738-758.

EL-Tarawy, O. M. (2017). Physiological studies on olive transplants. M.Sc. Thesis, Benha University, Egypt.

El-Tanany, M.M., M. N. Abdel Messih and M. A. Shama (2011). Effect of foliar application with potassium, calcium and magnesium on yield, fruit quality and mineral composition of Washington navel orange trees. Alexandria Science Exchange Journal, 32 (1): 65-75.

Epstein, E. (1999). Silicon. Annual Review of Plant Physiology and Plant Molecular Biology. 50(1): 641-664.

Ferre, D.C. and C.G. Forshey (1988). Influence of pruning and urea spray on growth and fruiting of square bound Delicious apple trees. J. Amer. Soc. Hort. Sci., 113(5): 699-703.

Garcia-Mari, F., C. Granda., S. Zaragoza and M. Agusti (2002). Impact of citrus leafminer (Lepidoptera, Gracillariidae) on leaf area development and yield of mature citrus trees in the Mediterranean area. J. Econ. Entomol., 95: 966-974.

Guntzer, F., C. Keller and J. D. Meunier (2012). Benefits of plant silicon for crops: a review. Agron Sustain Dev., 32: 201-213.

Heppner, J.B and T.R. Fasulo (2010). Citrus leafminer, Phyllocnistis citrella Stainton (Insecta: Lepidoptera: Phyllocnistinae). IFAS Extension, University of Florida http://edis.ifas.ufl.edu/IN165. Publication EENY-038/IN165.

Ibrahim, H. I. M and M. M. Al-Wasfy (2014). The primitive impact of using silicon and selenium with potassium and boron on fruiting of Valencia orange trees grown under Minia region conditions. World Rural Observations, 4(6): 28-36.

Jackson, M.L. (1958). Soil Chemical Analysis. New Jersy Prentice - Hall, Inc. Englewood, Cliffs, New Jersy. 
Jeschke, W.D and O. Wolf (1985). Na dependent net K re translocation in leaves of Hordeum vulgar cv. 'California Mariout' and Hordeum distichon cv. 'Villa' under salt stress. J. Plant Physiol., 121:211-223.

Johanson, D.A. (1940). Plant Micro-technique. ( $5^{\text {th }}$ edition) Mc. Grow Hill, Book, CO. Inc. N.Y. pp: 523.

Kadam, A.M., D.B. Singh and R.A. Kade (2011). Effect of plant growth regulators and potassium nitrate on growth of Rangpur lime seedlings. International Journal of Agricultural Sciences, 7 (1): 96-99.

Keeping, M.G. and J.H. Meyer (2003). Effect of sources of silicon on resistance of sugarcane varieties to Eldana saccharina Walker (Lepidoptera: Pyralidae). Agriculture and Forestry Entomology, 4: 265-274.

Khoshbakht, D., A. Ghorbani., B. Baninasab., L. A. Naseri and M. Mirzaei (2014). Effects of supplementary potassium nitrate on growth and gas-exchange characteristics of salt-stressed citrus seedlings. Hotosynthetica, 52 (4): 589-596.

Knapp, J.L., L.G. Albrigo., H. W. Browning., R.C. Bullock., J.B. Heppner., D.G. Hall., M.A. Hoy., R. Nguyen., J. E. Peña and P.A. Stansly (1995).Citrus Leafminer, Phyllocnistis citrella Stainton: Current Status in Florida. Coop. Ext. Serv., Univ. Florida, Gainesville: 26.

Laz, I.S. (1999). Anatomical studies on leaves of two olive seedling cultivars as affected by different levels of water irrigation. Zagazig $J$. Agric. Res., 26(6): 1731-1749.

Marquard, R.D. and J.L.Tipton (1987). Relationship between extractable chlorophyll and in-situ method to estimate leaf greenness. Hort. Science, 22, 1327.

Marschner, H. (1995). Mineral Nutrition Of Higher Plants. Second edition. 889pp. London: Academic Press.

Matichenkov, V., V. M. Galvert, and G. Snyder (2001). Silicon fertilizers for citrus in Florida. Proc. Fla. Sate Hort. Soc., 112: 5-8.

Mead, R., R. N. Currnow, and A. M. Harted (1993). Statistical Methods in Agricultural and Experimental Biology. $2^{\text {nd }}$ Ed. Chapman and Hall, London pp. 10-44.

Metwally, S.M.I., F. A. Abou-Atia., F. A. Sharshir and R. M. Helal (1998). Studies on citrus leafminer, Phyllocnistis Citrella Stainton at Kafr El-Sheikh governorate, Egypt. Menofya J. Agric. Res., 23(5):1261-1268.

Ministry of Agriculture and Land Reclamation (2014). Bulletin of the Agricultural Statistics, Part (2) Summer \& Nile crops, 2012/2013, Cairo, Egypt. 
Mortezaiefard, S.H., S. Kalatejari., V. Baniameri and M. Basirat (2012). Effect of sources and concentrations of potassium foliar application on yield, quality and leafminer infestation (Liriomyza trifolii) in gerbera (Gerbera jamesonii 'stanza'). Acta Horticulturae, 937:511-518.

Mustafa, I., M. Aslam., M. Arshad., S. Muhammad., M. Mustaqeem., S. A. Bokhari., S. Asif., M. R. Khan., A. Waqas and H. Ahmed (2014). Association of citrus leafminer, phyllocnistis citrella (lepidoptera: gracillariidae: phyllocnistinae) with leaf biochemical factors $\left(\mathrm{Ca}^{+2}, \mathrm{~K}^{+}\right.$and $\left.\mathrm{Mg}^{+2}\right)$ in kin now leaves of District Sargodha, Punjab, Pakistan. Pakistan J. Zool., 46(4): 953-958.

Nassar, M.A. and K.F. EL-Sahhar (1998). Botanical Preparations and Microscopy (Microtel chnigue). Academic Bookshop, Dokki. Giza, Egypt, p. 219 (IN Arabic).

Reynolds, O. L., M.G. Keeping and J.H. Meyer (2009). Siliconaugmented resistance of plants to herbivorous insects: a review. Ann. Appl. Biol. , 155:171-86.

Santos, M. C., A. M. R. Junqueira., V. G. Mendes de Sá., J. C. Zanúncio and J. E. Serrão (2015). Effect of silicon on the morphology of the midgut and mandible of tomato leafminer, Tuta absoluta (Lepidoptera: Gelechiidae) larvae. I.S.J., 12: 158-165.

Vianna, U.R., D. Pratissoli., J. C. Zanuncio., E. R Lima., J. Brunner and F.F. Pereira (2009). Insecticide toxicity to Trichogramma pretiosum (Hymenoptera: Trichogrammatidae) females and effects on descendent generation. Ecotoxicology, 18: 180-186.

Villanueva-Jiménez, J. A and M.A. Hoy (1998). Toxicity of pesticides to the citrus leafminer and its parasitoid Ageniaspis citricola evaluated to assess their suitability for an IPM program in citrus nurseries. Bio Control , 43:357-388.

Xiaopeng, G., Z. Chunqin., W. Lijun and F. Zhang (2005). Silicon Improves Water Use Efficiency in Maize Plants. Journal of Plant Nutrition, 27 (8): 310-315.

Zanetti, L. V., C. R. D Milanez., V. N. Gama., A. G. Marco., A. S. Carlos., E. F. Campostrini and A. M. M. Fábio (2016). Leaf application of silicon in young cacao plants subjected to water deficit. Pesquisa Agropecuária Brasileira, 51(3), 215-223.

Zhang, A.G., C. O'Leary, and W. Quarles (1994). Chinese IPM for citrus leafminer (Phyllocnistis citrella). IPM Practitioner., 16(8):10-13.

Zhiming, X., R. I. Song., H. Shao. F. Song., H. Xu and Y. Lu(2015). Silicon improves maize photosynthesis in saline-alkaline soils. The Scientific World Journal. Article ID 245072, 6 pages, 2015. doi: $10.1155 / 2015 / 245072$ 


\section{تأثير بعض مركبات السيلكون و البوتاسيوم والكالسيوم على العلى

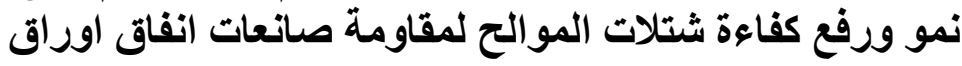 الموالح لمثاوه}

محمد محمد سعيد أبو العنين 1 ـ امل بهجت ابو القاسم² ـ أمجد محمد العزازى 1 ـ فيصل سامي السئل 1 ـ قسم بحوث المو الحــ معهد بحوث البساتين - مركز البحوث الزر اعيةـ القاهرة-

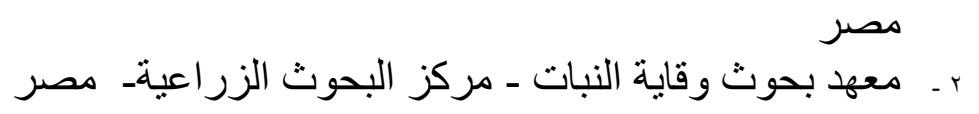

اجريت هذة التجربة ل لر اسة تأثير بعض مركبات السيليكون و البوتاسيوم

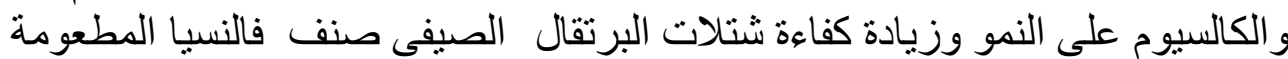

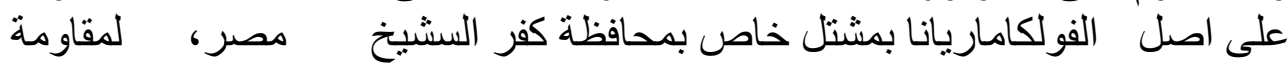

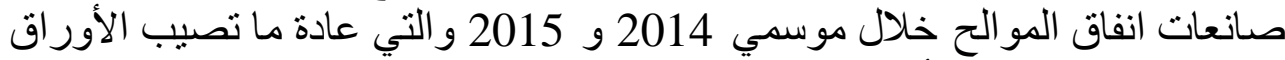

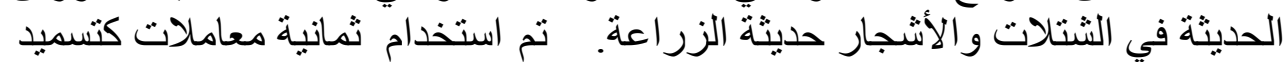

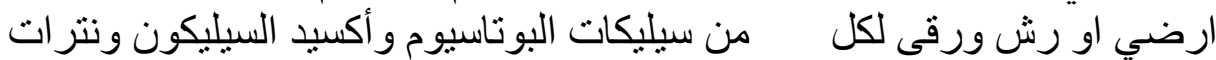

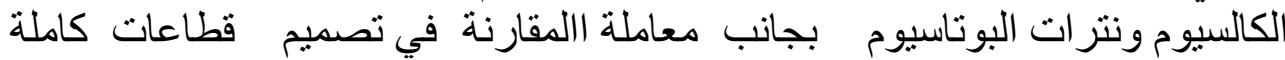

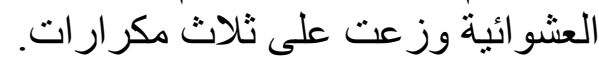

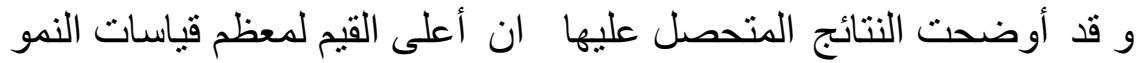

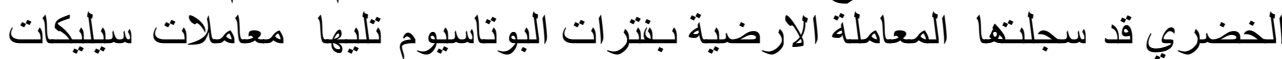

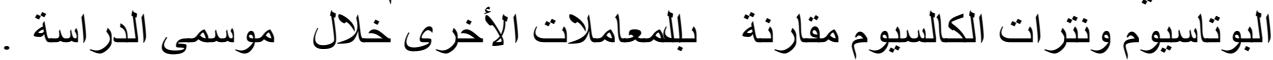

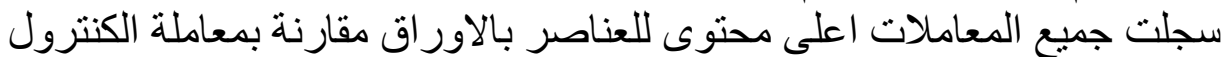

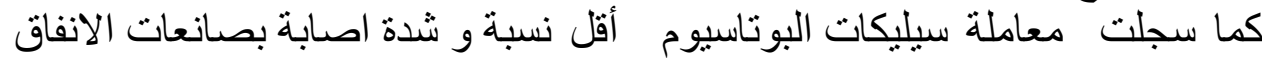

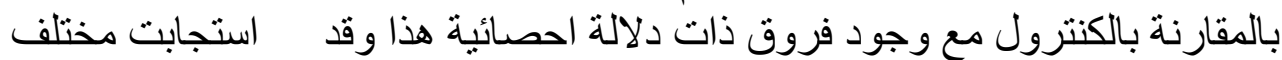

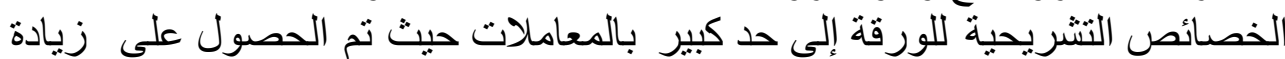

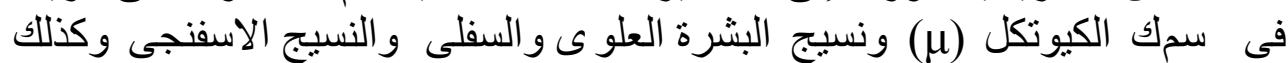

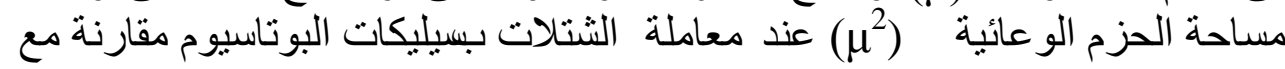
الصفات التشريحية لاور اق الثتلات التئة غير المعاملة.

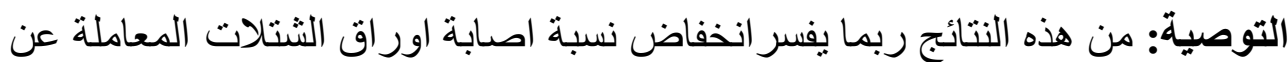

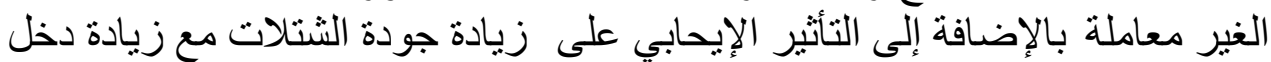

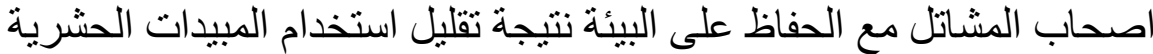

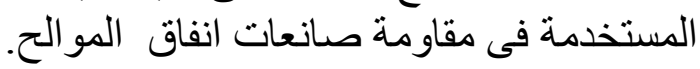

